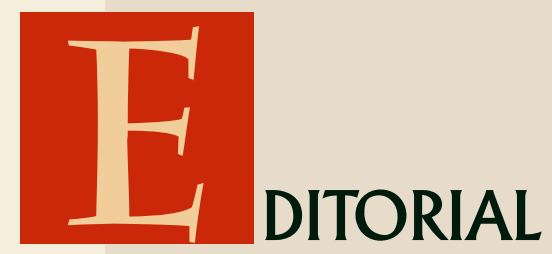

Jeanne Marie Machado de Freitas 1

\title{
Televisão: o enigma de nossos tempos?
}

A televisão ainda é uma quase desconhecida. A grande maioria dos estudos centram-se nas avaliações de audiências de onde saltam inferências inconseqüentes remetidas, invariavelmente, ao senso comum: o povo isso, o povo aquilo. Talvez o povo seja mesmo isso ou aquilo, mas o que sustenta tal remissão? O que representa a esmagadora emergência da televisão na contemporaneidade? A quais transformações corresponde? Quais transformações provoca?

O olhar, da televisão e do telespectador, é um olhar ingênuo? Direto? Televisão, a janela para o mundo? Ou, quem sabe, é o mundo que nos olha pela janela?

Caligrama contribui para o debate publicando três artigos os quais, com visões distintas, voltam-se para a telinha quer seja interrogando-a diretamente, quer seja lembrando os deveres que lhe são atribuídos.

E.Bucci, doutor em Ciências da Comunicação, detém-se na apresentação de conceitos novos: o telespaço público e a instância da imagem ao vivo em conexão com um tempo peculiar, o tempo sem tempo do gerúndio: acontecendo. $\bigcirc$ texto estabelece o progressivo esvaziamento das referências de tempo e de espaço no campo do jornalismo e das mídia em geral em um singular percurso por vários autores (R.Ortiz, W. Benjamin, T.Adorno, R. Garaudy, M.Augé e outros). O trajeto conduz a uma afirmação pertubadora: "A coincidência entre tempo do capital, tempo do espetáculo e tempo do inconsciente é uma particularidade histórica de nossa era".

S.H.Barbosa, doutor em Ciências da Comunicação e Editor-Chefe do Jornal da TV Gazeta, analisa o binômio educação e cidadania e a sua relação obrigatória com as redes midiáticas, especialmente a televisão, com base na chamada Constituição Cidadã. A discussão das pesquisas que visam as tevês comerciais brasileiras e norte-americanas destaca, em relação às últimas, as noções de Edutainment (Entertainment Education) e Merchandising Social provenientes da área de pesquisa Comunicação para o Desenvolvimento e que, 
de um modo ou de outro, balizam as atividades experimentadas no Brasil. Explora ainda as noções de cidadania e educação através das informações fornecidas pelas ONGS e, no final, oferece uma leitura das propostas que, possivelmente, regulamentarão o dispositivo constitucional e enfatiza a sua necessária urgência.

A noção (ou conceito? ou idéia?) de pós-modernidade é uma fonte permanente de discussões. A.D. Quadrado, mestre em Ciências da Comunicação e jornalista, retoma-a destacando contradições e paradoxos através de uma leitura inovadora dos autores que melhor pensaram a questão.

O trabalho do repórter na cobertura de esportes e das denúncias que envolvem os jogadores no caso de acusações de doping é o objeto do texto de L.V.B. Maluly, doutor em Ciências da Comunicação e professor de radiojornalismo na ECA.USP. O relato de vários casos permite indicações relevantes para o repórter esportivo, capacitando-o a democratizar o espaço que Ihe é destinado no jornal.

A.C.Pereira, professora do Curso de Jornalismo da Faculdade Sul Brasil, Paraná, busca definir o livro-reportagem. Sedia o trabalho no campo do discurso e propõe pensar a especificidade desse gênero, nem jornalismo nem literatura, através do modo de encenação do discurso relatado.

Os conceitos de focalização (G. Gennette) e de dialogismo (M. Baktin) propiciam a leitura das conexões entre a narrativa literária e o texto audiovisual como o demonstra L.A. Mousinho, Doutor em Teoria e História Literária, UNICAMP e professor no Departamento de Comunicação Social e do Programa de Pós-Graduação em Letras da Universidade Federal da Paraíba, no texto -Tem que ser agora: focalização e dialogismo no seriado Cidade de Deus.

Sandra Fischer, Doutora em Ciências da Comunicação pela Escola de Comunicações e Artes, USP, professora no Programa de Mestrado em Comunicação e Linguagens da Faculdade de Ciências Sociais Aplicadas e nos Cursos Especialização em Cinema, Graduação em Comunicação Social - Rádio e Televisão e Graduação em Design em Moda, da Universidade Tuiuti do Paraná, na leitura de Durval discos: interiores devastados, desenvolve a hipótese segundo a qual, os filmes intimistas, tendência recente do cinema brasileiro, apoiando-se nos recursos expressivos narrativos e rompendo com o poético e o estranhamento, revelam, no cotidiano, o drama do homem cindido.

A. Moraes, mestra em Letras e Linguística e professora de Jornalismo no Departamento de Comunicação Social, Universidade Federal de Goiás, mostra que escrever bem não é um talento inato e destaca as contribuições da Teoria Linguística para a aprendizagem da produção de textos.

A colaboração de M. M. Borges, doutor em Projetos e Produtos pela Universidade Federal do Rio de Janeiro, professor do departamento de Engenharia de Produção da Universidade Federal de Juiz de Fora, assegura que a linguagem visual é indissociável do processo de desenvolvimento de produtos e artefatos. Uma retrospectiva histórica nos faz ver a importância que o desenho e a linguagem gráfica assumiram no decorrer da história da humanidade.

T.M. Tellaroli, mestranda do Programa de Pós-Graduação Comunicação Midiática, da Universidade Estadual Paulista, apresenta uma revisão bibliográfica dos estudos sobre jornalismo online, identificando a atualização das notícias 
como uma das maiores dificuldades dessa modalidade jornalística. A análise de dois portais de Campo Grande, MS, permite atribuir a precariedade da atualização, ao modelo organizacional das empresas jornalísticas responsáveis, às deficiências operacionais e ao desconhecimento do leitor.

O arquivo retoma as pesquisas de M.X. Delli Carpini, Dean da Annenberg School for Communication, e B.A. Williams, Department of Political Sciences, University of Kentucky. No trabalho que agora publicamos, é ainda, a televisão o alvo do estudo. Partem da afirmação - o meio é a mensagem - não somente como uma forma de pensar os mídia, mas também como um modo de pensar como os mídia são estudados, isto é, os próprios métodos. A pesquisa se desdobra em três partes: explicitar as metáforas subentendidas nas pesquisas e suas relações com as metodologias empregadas; oferecer uma metáfora alternativa para a relação televisão e política; apresentar os resultados desses estudos prévios e, com eles, investigar empiricamente a relação citada.

R. de Lima Soares, doutora em Ciências da Comunicação e professora do Departamento de Jornalismo e Editoração na Escola de Comunicações e Artes,USP, na resenha Jornalismo e Cultura Juvenis, apresenta uma leitura do livro da repórter Raquel Cepeda, And it don't stop -The best American hip-hop journalism of the last 25 years.

Por fim, leitores de Caligrama, professores e alunos que desenvolvem estudos e pesquisas na área de Ciências da Linguagem em Mídia, nosso CALL FOR PAPERS já está no ar. Enviem-nos a sua contribuição, observando as normas da revista 